\title{
Environmental Governance in China
}

\author{
G. Venkat Raman \\ Humanities and Social Sciences, IIM Indore, Indore, India \\ Email: gvenkat@iimidr.ac.in
}

Received 28 April 2016; accepted 19 June 2016; published 22 June 2016

Copyright (C) 2016 by author and Scientific Research Publishing Inc.

This work is licensed under the Creative Commons Attribution International License (CC BY).

http://creativecommons.org/licenses/by/4.0/

(c) (i) Open Access

\begin{abstract}
The question of environmental governance has been of significant interest to the scholarly community in general and sinologists in particular. The current literature on environmental governance is researched and studied broadly under four domains, namely, globalization, decentralization, market and individual based governance, and cross-scale governance. In this paper one has tried to look into the question of environmental governance in a socialist market economy like China from the point of view of "decentralization". The word "decentralization" here is to be understood in terms of a) central-local relations and b) state-society relations. The paper discusses some of the critical aspects related to these two facts of environmental governance by referring to existing literature in the field of domestic governance and politics in China. Further, the paper discusses some of the measures undertaken in China to tackle the question of environmental governance. The question of environmental governance is currently undergoing a phase of transition with new forms of "collaborative governance" and new forms of "public private partnerships". However, what one gets to see that an apparently authoritarian China has demonstrated remarkable "political capacity" to constantly reinvent itself and been open to the idea of engaging the other stakeholders in tackling the problem of environmental governance.
\end{abstract}

\section{Keywords}

Environmental Governance, Decentralization, Central-Local Relations, State-Society Relations, China

\section{Introduction}

Environmental governance has attracted significant scholarly attention in recent times. For the purpose of this paper, environmental governance is to be understood as "synonymous with interventions aiming at changes in environment-related incentives, knowledge, institutions, decision-making, and behaviors" [1]. Some scholars like Maria Carmen Lemos and Arun Agarwal have referred to environmental governance as a set of regulatory processes, mechanisms and organizations through which political actors influence environmental actions and 
outcomes [2]. As mentioned in the latter sections of this paper, "governance" is different from the word "government" in the sense that the former word includes actions of state actors as well as non-state actors like NGOs, and businesses. This paper endeavors to look into the question of environmental governance in China. Given that academic scholarship on environmental governance is broadly divided to four domains, namely, "globalization, decentralization, market and individual based governance, and cross-scale governance", one would like to address the question of environmental governance in a socialist market economy like China from the point of view of "decentralization". The word "decentralization" here refers to two set of questions. The first refers to the question of central-local relations in the context of environmental governance while the second refers to the numerous ways in which the party state in China has engaged non state actors like NGOs (for instance, Party Organized NGOS called PONGOs and Government Organized NGOs) to address the issue of environmental governance.

The question of environmental governance in China is still in its infancy and this aspect of domestic governance and politics is still emerging. However, there is lack of actual micro studies with little primary field work based research. Having said this, one should qualify this by saying that of late there have been many works which add to our theoretical studies. This paper is an exploratory study of a critical aspect of governance, namely, environmental governance in the context of a country like China. To the academic community of Sinologists it makes sense to understand the relevance of environmental governance in contemporary times but to the larger academic community the question of environmental governance in China is more often than not, an intriguing one. Some of the questions in this regard include, what role, if any, local governments have in tackling the question of environmental governance in China; how the localities have managed to circumvent the centre's diktats regarding the various rules and regulations concerned with environmental governance and what is the rationale behind their actions; how does one account for role of NGOs and emerging civil society actors in a party-state like China. Jonathan Schwartz [3] who has researched in the area of environmental governance in China has cited two very critical factors which make a party-state like China a very interesting case study in environmental governance. First, the bureaucratic structure of Chinese political system provides valuable opportunities for comparative research among China's provinces, especially so because of the variations in enforcement efforts across provinces. Second, growing economic might of China brought about by rapid economic growth has led to environmental damage which in turn has fanned domestic discontent and in the process led to domestic instability in China. In fact, in recent times, the growing number of the so called "mass incidents" related to environmental pollution, especially in the rural areas, has attracted the attention of China scholars. In fact, environmental pollution happens to be one of the most important causes of rural protests and political instability in China. Scholars studying about environmental governance in China unanimously agree that environmental governance and issues related to sustainability have gained currency in policy making with more pronounced articulation of environmental interests only in the last decade or so. In fact, it was the publication of a report titled "Decision on Embarking on a Scientific Approach to Development and Enhancing Environmental Protection" in December 2005 that heralded the "third wave of environmental regulation" [4].

The word "governance" as shown later has been interpreted differently in different contexts. One approach has interpreted "governance" as different kinds of decision-making processes in different political systems based on "inter-action orientations that prevail among actors ranging from arguing or deliberation" [5]. The second understanding of "governance" as based on current academic literature on environmental governance is the common focus on debates revolving on the "role of the state in the society". This paper has taken a clue from these interpretations of "governance" and looks into the question of environmental governance in China by examining two indispensable constituents of China's policy making in environmental governance, namely, local governments and the ENGOS (environment NGOs). The following section provides the rationale for selecting these two vital components in analyzing environmental governance in China.

1) Central-Local Relations: Given that global environmental issues are invariably local in origin and that responsibility in the first instance rests with the local and regional administrative offices, the provincial or "local state" is bound to play an important role. Therefore central-local relations and their role in policy making and environmental governance constitute an important issue area. The economic and market driven decentralization in China and the adoption of the "eating in separate kitchens" [6] (fenzaochifan) policy led to economic development in the eastern coast of China at a breakneck speed. It took nearly twenty five years for the Chinese leadership to realize the costs of economic modernization. In the process, in the last decade or so Sinologists have been keen to see how the Chinese leadership has handled the question of environmen- 
tal governance and policy. In China's case, center's handling of environmental policy always had a zero-sum impact on the economic development priorities of the provincial leadership in China. This has led to what Cai and Tresman call "state corroding" caused by the various political "risks of decentralization". Academics dealing with the concept of "governance" have inferred from various studies that most of the political systems which experience a process of sustained interaction between a diverse set of actors, the actors with more resources end up imposing values on other less resourceful parties. In a party state like China it is obvious that the centre should call the shots but in reality despite the centre being the agenda setter and having more resources it is not very successful in translating its "state capacity" [7] to unquestioned compliance by the local governments. This has led to emergence of strong local level clienteles where local officials engage in crony capitalism, "imprecise norms" and abuse of political authority in one or other forms. Given this reality, scholars like Thomas Heberer and Anja Senz raise two important questions. First, to what extent local cadres have the autonomy to interpret and adjust the central directives which they refer to as "creative space" and second, what are the incentives and pressures used by higher level authorities to ensure proposed implementation of central directives. This problem continues to haunt the central leadership even today. For instance, even in today's China under the leadership of Xi Jinping, when there are calls of "new normal" it's not uncommon for provincial leaders to go for the "GDP oriented" mindset. How can one account for this fact? A study by Deng Yonghen of National University of Singapore (NUS) and Wu Jing of Tsinghua University in Beijing looked at careers of officials who had worked as mayors in 283 cities. It found that those who presided over higher growth rates were promoted to higher and influential positions [8]. Strangely, they also found out that those leaders who promoted increased investment in environmental protection ended up with lesser prospects of being promoted to higher positions. They concluded by saying that at lower levels of local government, cadres are still being judged by a GDP based appraisal system [8].

2) State-Society Relations: The Case of ENGOS (environmental NGOs) in China: In the last few years there has been a significant increase in environment NGOs in China. According to All China Environment Federation, the ENGOS have increased from 2768 by 2005 end to 3539 by 2008 . The Environment focused NGOs are a subject of much interest to China observers. In the recent past a strand of literature termed as "political opportunities" and "resource constraints" (for instance, quest for rare earth metals in the last ten years) theory has only facilitated further interest in ENGOS. According to this theory social movement organizations exploit opportunities resulting from changes in institutional structures and informal power relations. In the Chinese context, ever since the call for "harmonious society" made by former president $\mathrm{Hu}$ Jintao, the Chinese party-state has embarked on engaging the society to achieve "sustainable governance". Sinologists cite various reasons for loosening grip of the Chinese state over the society, like, diversification of Chinese society in the course of unfolding of the economic reforms in the past two decades, the Chinese state's willingness to "negotiate" with the society, increasing conflicts within the government vertically and horizontally leading to political space for ENGOS.

This paper is organized as follows. The first part deals with various conceptual issues related to the concept of "governance" and attempts to locate the question of environmental governance in the domain of policy making. The second part deals with a brief description of the evolution of environmental policy making in China. The third section comprises of scholarly arguments to analyze the reasons underlying the policy and implementation gap in dealing with the problem of environment. The fourth section would deal with the question of environmental governance in China and discuss it in the light of centre-local relations and state-society relations with a focus on environmental NGOS (henceforth ENGOS). The final section would make some concluding observations on the "political capacity" of the Chinese state in terms of its ability to enforce its administrative fiat. One finally concludes by touching upon the utility of having a more healthy engagement of among BRICS countries in unconventional arenas like environmental governance, disaster management, public-private partnerships, and etcetera. The BRICS countries can exchange knowledge, innovative measures on the bases of indigenous technology to come up with uniquely non-western solutions to global problems. This is especially useful in opening up avenues for co-operation among developing countries like the BRICS nations to engage with each other in various aspects of governance including environmental governance.

\section{Governance, Environment and Policy Making}

In common parlance some have tended to confuse the concepts of "government" and "governance". According 
to Jan Kooiman, the true import of the meaning of "governance" can be understood by distinguishing it with two related words, "governing" and "government". "Government" and "governance" are ways of governing society, but whereas government is the concrete form of state, governance involves a wider set of actors ranging from elected representatives to various non-elected non-state actors like trade and commercial associations, civil associations, interest and pressure groups, etcetera. This distinction is further validated by contending that "government" refers to a top-bottom method of governing whereas "governance" is something which is more bottom-up than top-bottom and involves a partnership between government and non-government actors in the domain of the society.

In the context of China, especially in the 1990s and 2000s the growth and indigenization of the new disciplines of public administration and public management progressed very rapidly in China. Moreover, the growth of the market economy led to a situation in which the government along with corporate and business organizations and civil society organizations was just one of the service providers. Governance, thus, was not mere control over the populace but about being service providers. Thus China didn't need public administration but public management (gonggongguanli). Public management extends its scope from the administrative apparatus of formal government to the whole public sector. This includes the legislative and judiciary organs, state-owned enterprises, political parties, and mass and community organizations. It is pertinent to note that under this field the government continues to play a vital role in China, but non-governmental organizations were given a role to play as well.

With this conceptual understanding of "governance", one would like to examine environmental governance in China. In fact, we come across terms like "environmental states" in contemporary times and it is possible to compare what various states are doing to address the problem of environmental protection and "sustainable governance". This genre of literature enshrines environmental protection as a basic goal and advocates the commitment of institutional resources towards the formulation and execution of a variety of actions indispensable in promoting the cause of "ecological integrity". The so called "environmental rationalization" of states' roles critically depend on types of linkages between nation-states and actors within civil society. Scholars have, broadly speaking, attributed two broad motives for state action to promote "sustainable governance", namely, "legitimation" and "rationalization" [9]. In the initial stages, states adopt symbolic and discursive methods to legitimize their authority but there are no significant policy changes to promote sustainable governance. However, states adopting "sustainability" as a central responsibility have led to various efforts to improve efficiency and effectiveness of environmental regulation by adopting changes at the level of "policy-making". Scholars researching in the area have observed that earlier, governments tended to rely on regulatory mechanisms based on "mandatory operating requirements, inspection and enforcement, which in many instances has proved successful". Over a period of time this kind of direct regulation has paved the way for harnessing of other non-state actors in the society like civil society organizations and corporate entities. This latter approach has led to a clear shift in environmental policy making from one driven by governance to one based on "governance" in which state involves non-state actors and tries to solve contemporary challenges in different societies ( refer Figure 1).

Oliver Treib, Holger Bahl, Gerda Falkner maintain that it is necessary to distinguish between "governance" and "modes of governance". The term "governance" has come to mean various things to various scholars in the field of policy making. For some scholars it means "politics" whereas for others it "system of rules" and still for some others it means "mode of political steering". Talking about governance as "politics", some scholars like Rhodes have used governance to describe a process of policy formulation in which state actors share power with private actors. As per this understanding, policy formulation takes place within interorganizational networks characterized by inter-dependence and resource exchange. According to Renate Maynatz "governance" is a "system of rules" that shapes actions of social actors. This school of thought identifies different modes of "governance" as opposing ideal types of "market" and "hierarchy" [10]. Adrienne Heritier on the other hand and more interestingly describes governance as a mode of "political steering". He further argues that policies can be distinguished according to steering instruments which enable us to define how policy goals should be realized to attain certain societal outcomes. In this paper one would look at the word "governance as a "mode of political steering" and look at central-local relations and "state-ENGO relations in China towards attaining "sustainable governance".

Policy making in environmental governance irrespective of one based on administrative fiats issued by the "government" or by various instruments of "governance" raises the critical question "what instruments work, when and with whom and why?" across different political systems. 


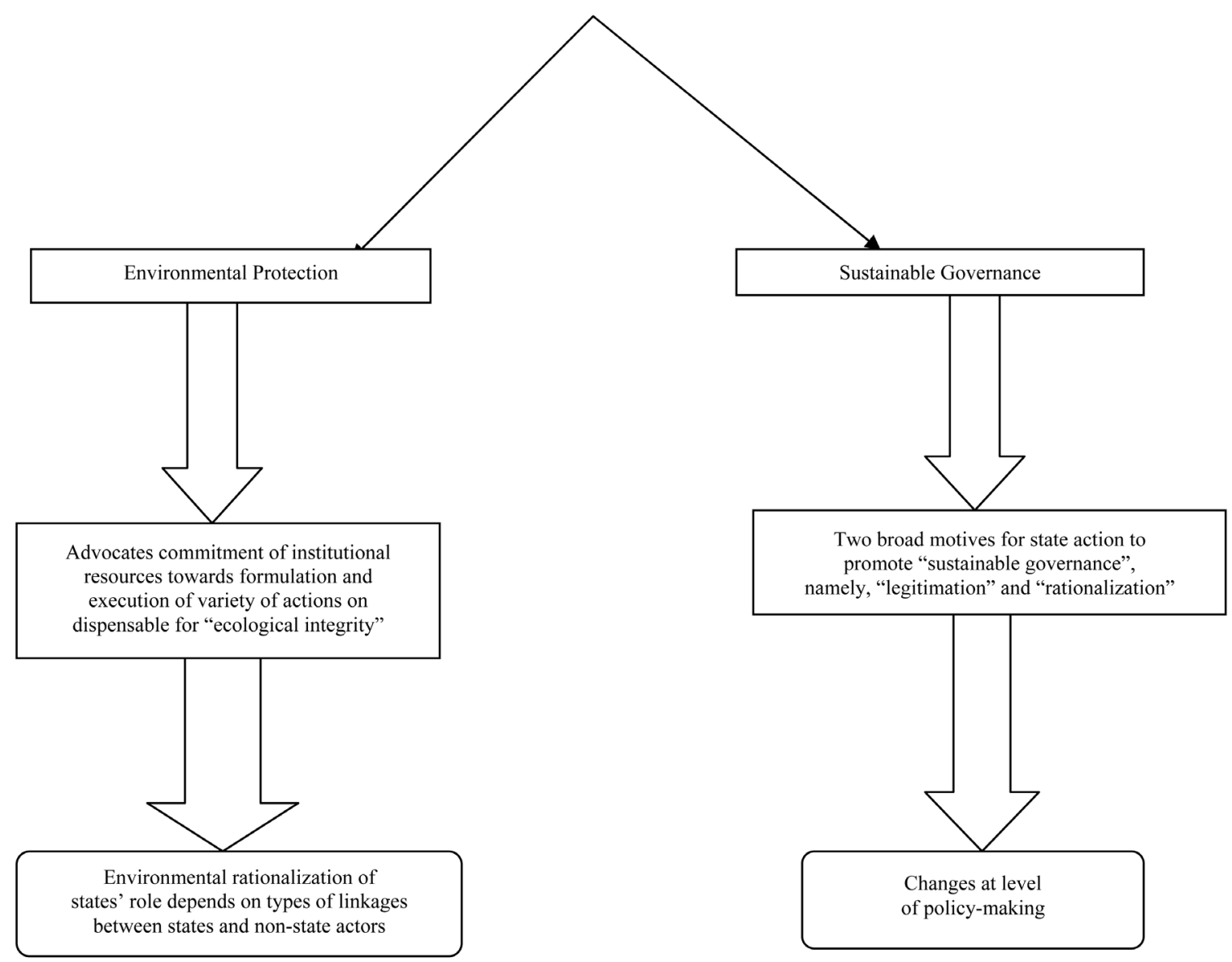

Figure 1. The Environmental State as Depicted in Current Literature.

Environmental issues are characterized as "ill-defined, tightly coupled with other sectors and questions, and reliant upon elusive and transitory political agreement for their resolution" and thus are "wicked" or "multi-faceted" [11]. A very interesting feature of environment as a policy making domain is its "paradoxical" nature, as a result of which, there are divergent understandings and comprehension of various issues related to environment. Whereas the "state" is pre-occupied with policy-making and in the process deeply involved with problem-solving, the "society" happens to have a more enriched and detailed knowledge of the local ecological conditions, although at times, its various counter-claims lack sound and rigorous scientific bases.

Policy making in the field of environment acquires special significance because not withstanding different political systems, the state invariably finds it difficult to resist the temptation of involving the society. There is broad agreement among a range of scholars on the likely factors inspiring the state to engage the society in tackling the various questions involved with environmental governance. First, involvement of the society helps to achieve sustainability and design innovative policies. Second, it helps check various bureaucratic and administrative tendencies which focus on absolute solutions (which are very difficult to arrive at) by facilitating continuous ongoing dialogue with various stake-holders. Third, society's involvement broadens the scope of relevant knowledge and improves social acceptability and legitimacy of innovative environmental policies. This has led to evolution of the concept of "collaborative governance" in the field of environmental governance. Peter Shergold, a passionate advocate of "participation society" suggests that co-operative solutions are required not only in the form of cooperation but between governments but also through co-operation between governments, CSOs and other stakeholders [12].

The existing literature on environmental governance speaks about five different types of regulatory policy apparatus, namely, direct "command and control", economic instruments, information based instruments, co-regulation and self-regulation and support mechanisms and "capacity building" [13]. In the case of the 
BRICS countries the policy makers consider alternative mixes of environmental instruments while choosing different development paths [14]. For instance, China and India both have shown to varying degrees usage of various alternatives to direct environmental regulation.

Six conceptual perspectives can be identified in current literature on environmental governance leading to a more nuanced understanding of environmental governance, namely, pluralism, agency capture, ecological Marxism, social constructionism, economic modernization and global environment. At the risk of being digressive one would like to briefly mention these various approaches [15]. Pluralist perspective helps us understand how government institutions aggregate multiple competing interests in the environmental realm to produce effective policy. Of all the six types mentioned here, environmental policy-making in China comes close to the "pluralist perspective" and "agency capture". "Agency capture" perspective looks at the constituency of resource users, particularly in the local context where formal authority holds less historical legitimacy. The "ecological Marxism" perspective focuses on how states are constrained by the logic of capital either at the national or world systems level. Ecological modernization perspective offers a more optimistic view by seeking to explain the various means adopted for environmental governance leading to institutional transformations in industrialized systems. "Social constructionism" enables us to examine "how people assign meanings to the world" around them. This perspective has much to offer the realist environmental social scientists who interpret environmental claims of state actors, scientists, social movements and other stakeholders. The "global environmentalism" perspective enables us to understand how various international environmental regimes and state and non-state actors in the international arena prompt various states to play an active role in "sustainable governance".

\section{Environmental Policymaking in China}

In the recent times the topmost leadership has paid a great deal of attention to the question of environmental protection and has played an influential role in "agenda setting" as regards providing a new thrust to environmental policy making. In 2005, the then president of China, Hu Jintao while addressing a symposium on population, resources and environment organized by the central committee of the CCP called for reestablishing of the environmental system of supervision and management in the form of guojiajiancha, difangjianguan, and danweifuze (centre investigates, locality administers, work units to be responsible) . In fact, the MEP went on to establish six regional supervision centres for environmental protection (SCEP) in east, south, north-west, south-west, north-east and north China respectively. The mandate of the SCEP is to supervise, inspect, mediate and provide services. In the Sixth National Congress on environmental protection sponsored by the state council the then Chinese premier Wen Jiabao stressed on the "three transformations", namely, transformation from an economy centered development to a development model which gives equal preference to environmental protection and economic development, from a policy of "develop first, clean up later" to a policy which gives balanced attention to environmental protection and economic development, from a purely administrative measures led policy making to one based on "comprehensive system based on involvement of the state, business and civil society. In the more recent times, Chinese premier Li Keqiang, while chairing an executive meeting of the state council asserted that it is a legal requirement in China to disclose government information [16]. He further contended that public participation in environment and development is a necessary part of the decision-making and policy formation and is a critical input in building an "ecological civilization". Probably premier Li was referring to public complaints and various redressal mechanisms to be adopted to facilitate public participation in the field of environment. In fact, the MEP operates a hotline $(12,369)$ which allows public supervision of enforcement of environmental regulations through telephone tip offs about pollution incidents. One of the recent policies which allows for publication of official data which was previously a state secret has been welcomed as a landmark development in China's quest for a "scientific concept of development" and environmental governance [17]. Before this bold step was taken the official stance was to push facts under carpet and disown the highly unhealthy and nauseating pollution in the country. This new rule is being construed as a major step towards openness [18]. For instance, in 2012 only a few cities like Beijing published statistics on air currently but today 179 cities participate in such transparent methods [18]. More importantly even firms are volunteering information about pollution-especially those that need foreign investors. Among other things, the new regulations require even some of the biggest SOEs to make public in real time details of their air, water, and heavy-metals 
discharge [18]. Though the current "political will" to deal with the menace of pollution seems to be somewhat unprecedented, the Chinese state did have some inkling about the likely impact that its quest for "modernization" would have on its environment. This is borne out by the environmental policy-related documents since the mid-1970s.

It was in 1974 that an Environmental Protection Bureau (henceforth EPB) was formed with a staff size of twenty. In 1982, the EPB was incorporated into the ministry of urban and rural construction. Six years later, in 1988, the EPB was separated from the urban and rural construction ministry and a separate environmental bureau was established. In 1990 the National Environment Protection Agency (NEPA) was formed with a staff of 120-320 people. NEPA was upgraded to State Environment Protection Agency (SEPA) in 2003 and then in 2008 it became a full-fledged ministry in the state council in the form of the Ministry of Environmental Protection (MEP). It is interesting to note that in the year 2002 the Chinese government for the first time, even allowed Chinese environmental NGOs (ENGOS) to participate in the world summit on sustainable development in Johannesburg in 2002 independently of the official delegation.

In the recent times even some local governments have initiated innovative methods to facilitate public participation in environmental protection in China. The Shanghai government has had several three year action plans since 2000. In the year 2008 an amount of 42 billion RMB (6 million USD) which accounted for 3\% of Shanghai's GDP was invested for promoting the cause of environmental protection and aiming to become a national model city of environment protection and an ecological city from the year 2009 [18]. In the more recent times the Shanghai mayor Yang Xiong has asserted that the local government would impose the "strictest" ever regulations on available land protection and land use, and the drawing up of a plan to protect and manage the soil. In this regard 660 low performing facilities were phased out in Shanghai and again in the year 2014 nearly 500 heavily polluting installations and facilities are to be phased out [19]. The Shanghai government also established a public welfare park in Pudong district where the state government has constructed modern buildings that house various support services and then contracts with NGOs to provide community services. For instance, the Chongqing EPB has facilitated innovative communicative platforms between governments and public that has proved to be highly effective. A series of micro-blog accounts have been started on websites like sohu, sinaweibo. The local EPB officials are given specialized training on using and co-coordinating the micro-blogging effectively [20]. The evolution of environmental policy making in China can be summed up in the form of the "three waves" mentioned earlier in the paper. Table 1 portrays the "three waves" of environmental governance in China.

Table 1. Three waves of environmental policy-making in China.

\begin{tabular}{|c|c|c|c|}
\hline Wave & Dominant Policy & Salient Features & Examples \\
\hline First & $\begin{array}{l}\text { Command and } \\
\text { control system }\end{array}$ & $\begin{array}{l}\checkmark \quad \text { Establishment of Environmental } \\
\text { Protection Bureau (EPB) }\end{array}$ & $\begin{array}{l}\text { EPB established in } 1974 \\
\text { and in } 1982 \text { incorporated } \\
\text { into ministry of urban } \\
\text { and rural construction }\end{array}$ \\
\hline Second & $\begin{array}{c}\text { Adoption of policy } \\
\text { Instruments to pursue } \\
\text { environmental governance }\end{array}$ & $\begin{array}{ll}\checkmark & \text { 1990: National Environment } \\
& \text { Protection Agency (NEPA) was formed } \\
\checkmark & \text { 2003: NEPA upgraded to } \\
& \text { State Environment Protection Agency }\end{array}$ & $\begin{array}{l}\checkmark \quad \text { In } 2002 \text { allowed ENGOs } \\
\text { to participate in world } \\
\text { summit on sustainable } \\
\text { development in Johannes burgh }\end{array}$ \\
\hline Third & $\begin{array}{l}\text { Scientific approach to } \\
\text { development and } \\
\text { environmental } \\
\text { protection (2005) }\end{array}$ & $\begin{array}{l}\checkmark \quad \text { "Agenda-setting" for environmental governance } \\
\text { by reaching out to other stakeholders } \\
\checkmark \quad \text { Legal requirements to disclose information } \\
\text { to government } \\
\checkmark \quad \text { 'Three transformations': } \\
\text { a) Equal preference to environmental } \\
\text { protection and economic development } \\
\text { b) From an economy centre development to } \\
\text { a development model which gives } \\
\text { preference to environmental } \\
\text { protection and economic development } \\
\text { c) From purely administrative measures } \\
\text { to comprehensive system involving } \\
\text { state, business and civil society }\end{array}$ & $\begin{array}{ll}\checkmark & \text { Ministry of Environment } \\
& \text { Protection's } 12369 \text { hotline } \\
& \text { allowing public supervision } \\
& \text { of enforcement of } \\
\text { environmental regulations } \\
\checkmark & \text { Publication of official } \\
& \text { data on environmental matters } \\
\text { which till recently was } & \text { treated as official secret } \\
\checkmark & 179 \text { cities have transparent } \\
\text { data on matters related to } \\
\text { environmental regulations }\end{array}$ \\
\hline
\end{tabular}




\section{Environmental Governance and Central-Local Relations}

Thomas Heberer and Anja Senz in their research on environmental governance in China [21] have put forward a three-fold role of the centre when it comes to policy-making in environment. First, it plays the role of the agenda setter which can be described as a series of standards or benchmarks that are fixed in documents which represent the intentions of the party-state and the various priorities which it sets for itself. Second, even as the agenda is finalized, the central policy makers are realistic enough to acknowledge the highly diverse characteristics of China and therefore permit local governments to implement the new central directives factoring local conditions. Third, the centre establishes cadre responsibility and evaluation systems. According to Zhou Xueguang, a sociologist by training and an experts on issues related to rural governance in China, there are three degrees of flexibility, namely, a) "flexibility" by purposive design b) "flexibility" of "unintended design" and c) "flexibility" by spatial interests. The "flexibility" of the centre is expressed in various ways like "adaptation to local conditions" ("horses for courses" policy); execution of very hard targets; local transformation of "soft" targets to "hard" targets; and "model creation" as a local policy innovation. Just like in the case of other major issues confronting China, the environmental policy making seems to be related in many ways to the question of cadre responsibility system. In the case of the environmental policy making and implementation the centre uses various methods like incentives, controls and constant inter-actions with the local governments. The cadre responsibility system is assessed through programme and performance evaluation, and periodical priorities (yipiaofoujie). Although the centre devises various mechanisms through which it can ensure cadre compliance, scholars researching on Chinese political system have time to time pointed out how the current five tiered Chinese political structure has led to a system of cadre accountability to the authority which is placed immediately above it and in the process one gets to see very little alignment in interests and/or synchronization in policy making between centre and local officials. The local officials and cadres are aware that their promotion and career prospects are in the hands of their immediate bosses and this leads to undesirable policy outcomes. For instance, the constant tension of local officials to be dictated by GDP targets because ultimately their career prospects hinge on this factor. In the case of environmental policymaking and implementation it is very important to highlight that despite the leadership of Hu Jintao and Wen Jiabao on "social governance", even today many of the cadres still uphold economic development and GDP growth as the key determinants of their upward mobility.

Scholars have attributed different reasons for this gap between centre's strong emphasis on "environmental" policy making and the evident low level of desirable outcomes. Some scholars like Huan Qingzhi have focused on the question of "political will" of the leadership while some studies by the World Bank have looked at "strategic planning" and "implementation gap". Li Wanxin and Paul Higgins have argued that what is considered as "political will" is actually a function of the orientation of individual officials, the context of political and administrative systems and the various local economic conditions. Zhou Xueguang, Hong Lian, Leonard Ortolans and Ye Yinyu [22] have extensively discussed the two models, namely, "tournament model" and "muddling through". The "tournament model" proposed by Zhou Lian proposed to explain the various incentives created by the central government to influence the behavior of local officials in China. Although certain benefits like, introduction of competition within an organizational hierarchy is based on rules by the principal (the central government), eliciting valuable information about the agents' performance gained at low cost, there are various drawbacks with the model, namely, collusive behavior of local officials and selective implementation of state policies. However, Zhou Xueguang and others have tried to account for "compliance and deviance" at the same time. They have used Charles Lindbolm's theory of "muddling through" and have forcefully argued how bureaucratic and political authorities behave and have put forward the "behavioral model". Zhou and others contend that the authorities at different levels are spurred by various contending logics which are often incongruent and generate conflicting responses due to the "logic of meeting targets", "coalition building" and "logic of incentive provision" leading to a specific set of outcomes. They further argue that the competing logics are more reactive than pro-active and are characterized by strategies improvised in response to multiple directives and targets set at higher administrative levels. Furthermore, they argue that constant readjustment is as important a strategy for coping with conflicting pressures generated by multiple bureaucratic logics. This leads to constant readjustments like allocation of attention, associated distribution of resources and in turn affects desirable and optimal outcomes. The limited attention leads to organizations exhibiting behaviors at odds with the rational model of decision-making and focusing on short term goals rather than long term goals. We can cite two instances where one can see the "muddling through" approach and the way it affected the behavior of the authori- 
ties. In the first case, Zijing Mining, a company in the mining sector contributed to almost sixty percent of local revenues to Shanghang county in the Fujian province and ended up winning a prize for "corporate integrity" in a particular year despite causing series of pollution incidents. To cite another case, large state owned enterprises do not face regulations from local governments in China. In June 2013, a company called Anqing Pec, under Sinopec was fined for the first time by the local environmental protection bureau for air pollution, although the company had been polluting the air for the last forty years. These instances lead to what some scholars have labeled as the phenomenon of "strong company, weak government" in China.

\section{Environmental Governance, State and ENGOS}

Within the state-society framework regarding environmental governance, the available literature throws up five paradigms, namely, "state-centred", "society centred", "state-society", "historical" and "globalized" approaches. However, before examining these approaches, it would be useful to briefly look at the evolution of NGOs in China. Scholars trace the origin of ENGOS in China to 1979 when the Chinese Environmental Science Institute was established. However, it was only after the establishment of NGOs like Friends of Nature (founded by Liang Congjie and considered one of the earliest ENGOS), and Global Village, Beijing, that international NGOs like WWF and Greenpeace are ardent advocates of environmental activism were allowed to operate and became a major component of NGOs in China [23]. There are currently more than 3500 ENGOS in China but they lack financial support [24]. The GONGOs (government supported NGOs) and PONGOs (party supported NGOs) in China work in various sectors in the form of foundations, charities. The purpose of the GONGOs and PONGOs is to receive support from various multilateral and bilateral INGOs; strengthen technical and information support and resolve new social problems. In some provinces and municipalities efforts have been made to facilitate greater involvement of international NGOs. For instance, the Shanghai municipal government is supporting an initiative to improve Shanghai's environmental performance. The United Nations Development Programme (UNDP) and China Council for International Co-operation on Environment and Development (CCICED) have entered into an agreement with Shanghai Municipal Government in supporting Shanghai municipality to improve its environmental performance and assist the authorities to make Shanghai an environmental friendly city. This project involved designing and implementing an Environmental Friendly City Index (EFCI), integrating environmental concerns into development planning and decision making through use of EFCI, public awareness building, establish private sector and sister city partnerships.

The numerous studies on state-society relations in China have effectively blasted the myth of China as a monolithic and authoritarian structure. Vivienne Shue has advocated focus on "the mutually conditioning interactions between elements of state and elements of society" or on "shifting arenas of state-society struggle and accommodation". Scholars like O "Brien and Kang Xiaoguang under the broad rubric of "developmental state" theories have sought to capture the intimate relationship between certain social and state actors in the interests of mutual enrichment that have descriptively characterised much of post-Mao politics. O Brien has put forward the concept of "entwinement" through which he argues that social actors voluntarily seek embeddedness in the state in order to attain legitimacy and value. Kang Xiaoguang speaks about the system of "graduated controls" while Ho and Edmond discuss "embedded activism". Kelly Tsai argues in her works how state-society inter-conditioning is rare and argues that the structural links between the state and society are not only present but also binding on both. David Goodman argues that the "CPC" (Communist Party of China) remains central to politics at central and provincial levels" but argues that at local levels a state-society bond with local entrepreneurs "provides the platform for the exercise of state power".

There are also a section of scholars like Kate Xiao Zhou argues that with regard to broad and important issues like economy, information, media, peasants, migration, sexuality and globalization, one does get to witness cases of state transgression. Lynn Whyte III also forcefully argues about "unstately power" while highlighting how one can trace local origin of reforms. Whyte argues that local state is a product of local society and he even goes to the extent of making a case for "kicking the state back out since that" happens to be exactly what de facto non-state institutions have begun to do". This work is also widely referred, for understanding internal pluralisation of the state in the reform era. In the context of various models of policy making, Wang Shaoguang refers to the "popular pressure" model which discussed various ways in which the public in China has been successful in setting the agenda of policy making in China in recent times in China.

In an earlier section there was a brief reference of the differences between "governance" and "government". It 
bears repeating that "governance" suggests more than just involvement of public agencies in formulation and implementation of policy. In the words of Frederickson and Johnson, "governance is no longer about who takes the office and under whose jurisdiction a particular matter falls, rather the question is who is included in the policy negotiation and implementation". It involves processes that engage in "multiple institutions that act in partnership to develop and deliver public policies and services". Scholars who have examined state-society relationship in East Asia have categorized the discourse into "bureaucratic-oriented politics", "state-society synergy", "soft authoritarianism" and "east Asian corporatism". McEachern, a scholar who has worked on state-society relationships in East Asia argues that the corporatist state in this region has been successful in economic development but performed poorly in responding to social demands such as demands for housing, environment, and health. To overcome this, the state through the processes of "incorporation", "assimilation" and "adaptation" deals with non-state actors in different ways. During the Maoist period, it was believed that "men can conquer nature" and subsequently, with the inauguration of market reforms under Deng Xiaoping, a renewed emphasis was laid on the "four modernizations". However, empirical research and field reports on civil society and voluntary based organizations in post-Mao China highlight that ENGOs were among the first to have originated in the reforms era. Research has also shown that ENGOs have consolidated their linkages and connections within the activism community over a period of time and have articulated shared principles. However, there are two striking features of the findings in this domain of academic research. First, there are numerous instances of sharing of experiences between the ENGOS inter se and second, constant mutual learning as to how to interact with authorities with consequent recognition that these associations have received from the state. In the case of the latter, the growing "activism from below" and the pushing of state boundaries through multiple tools of manipulation, is a significant development. One also observes an accumulation of practical knowledge in terms of decoding the official language and symbols. This has been referred to as "pushing the envelope" by Jenifer Turner, and "boundary spanning attention" by Kevin O' Brien. This has also prompted some scholars like Thomas Heberer and Grunow Dieter to approach the question of environmental governance in China by shifting their focus from what they call "effect evaluation" to "process evaluation", a shifting of attention from "specific implementation perspectives" to governance principles that includes civil society actors [24].

The working of ENGOS has attracted great scholarly attention in recent times. Following the seventeenth Party Congress, party leaders claim to be "testing waters to develop positive functions of civil society and religious organizations" in the hope of creating a "modern civil society" by 2020 [25]. Thornston Patricia in her research opines that "resurgence" of civil society as counter to the party state has given way to complex theorization regarding the "blurred boundaries" between the two, the way in which civil society organizations "negotiate the state" by "chipping away the edges" of its restrictive regulatory and legal frameworks. Andrew Mertha refers to savvy "policy entrepreneurs" working in and through NGOs entering policy process. There are also some studies which emphasise the need to study the CPC's objectives in the establishment of PONGOS (party organized NGOs) under the philosophy of "big party, small state, great society". Some scholars have argued that the third realm(di san bumen) envisions a new relationship between social groups and the Party independent of the state, particularly as the government withdraws from social welfare and public goods provision like environmental protection, social security, public health, etcetera.

The burgeoning literature in the field has also come up with what Jessica Teets calls, "consultative authoritarianism" to describe the current trend of growing official toleration of social pluralism as witnessed in permitting NGOs to have their own staff, resources and projects and some of these projects have even been collaborative ones with the local government playing an active role. In the recent times there has been more than an adequate administrative and economic devolution but this has not been accompanied with a simultaneous political devolution. With increasing local demands for public goods and services and decreasing funds most of the local governments operate on very tight budgets and as a result there has been a yawning gap between responsibilities and funding thereby motivating local governments to view civil society organizations as potential partners in securing international funding. This is also accompanied by an attempt to look for innovative models in policy making. Furthermore, the increasing autonomy of civil society organizations in China, many of which are even supported and backed by the government and the party has contributed to increasing scholarly attention on nature and functioning of these organizations. Lu Yiyi, for instance, argues than despite various limitations, in general the NGOs in China have been able to maintain their autonomy under the "dual management system" (shuang zhong guanli tizhi). Some scholars have also applied Migdal's theory of "state-in-society" approach to examine the functioning of the NGOs in China [26]. Migdal asserts that "patterns of domination are determined 
by key struggles spread through multiple arenas of domination and opposition and officials at different levels of the state are the chief factors in these struggles, interacting and at times even conflicting with an entire constellation of social forces in disparate arenas". Andrew Fulda and Li Yanyan have approached the question of state-NGOs relations in the form of "networks governance" and have argued that both the sides are likely to engage each other and willing to accept the organizational interests of their counterparts.

\section{Conclusions}

A state can be viewed as possessing high capacity if it can create durable institutions that survive the strains of leadership transition and if disputes are resolved through non-violent, political means. To conclude, one would like to make the following observations. In the recent times, the Chinese leadership especially at the central level has been very unequivocal in explicitly stressing the relevance of environmental governance. However, given the vast territorial landscape and highly challenging diversities, a uniform approach to economic development and modernization is out of the question. Furthermore, the Chinese leadership's approach to policy making is undergoing a phase of transition where there are more instances of "collaborative governance" and new forms of "public private partnerships" to address the problem of environmental governance. The Chinese state has always demonstrated a very strong "political capacity" [27] but has equally shown remarkable resilience and a rare capacity to constantly reinvent itself and keep in step with changing times. In the process it has always been open to the idea of negotiations and bargaining but has ensured that the provincial leadership does not dictate terms.

In recent times scholars like Kim Heung Kym have used the concept of "political capacity" as against "state capacity" [28] to demonstrate that Beijing (centre) has been capable of asserting more control during the postMao era. Kyu [29] has also applied the concept of "political capacity" [30] to prove that the centre in China is still powerful enough to draw compliance from the provincial leadership and the centre has in no way suffered any decline in its strength or capacity. Political actions in such terms are far beyond efficiency maximizing behavior or based on rational choices. Political leaders may ascribe varying qualities to different policy priorities and goals. Thus, "political capacity", in transitional authoritarian politics, is crucial in determining success in governance and this capacity of the Chinese state is most likely to have a very deep impact on China's environmental management, governance and policy-making.

The underlying conviction of this study of the Chinese experience is that one firmly believes that one of the various ways in which the BRICS nations as a grouping can significantly expand their relevance is by exploring opportunities to learn from each other in terms of policy making and in the process facilitate intra BRICS cooperation. This is bound to lead to positive spin-offs as regards their mutual trust and in the process will provide greater thrust to their aspirations to fight for a more just international system. One of the most important areas of cooperation between BRICS countries is in the field of sustainable development, environmental management and environmental governance, for a variety of reasons. First, although the BRICS nations have admittedly benefitted from globalization, they have equally been subject to the flip side of globalization and suffer from problems like poverty, widening inter personal income gaps, socio economic inequalities and accompanying social tensions. BRICS nations can collectively discuss these issues and find out means to develop cooperative mechanisms to address issues like health, hunger, energy, environment, and etcetera. Second, the BRICS nations have also experienced major natural disasters which have exposed the glaring deficiencies in their disaster management mechanism. Third, food security, energy security, clean drinking water, health concerns are all other related to in one way or other to the problem of environment. Fourth, this has necessitated the local officials to partner with the various social groups including those from the world of business in the form of public private partnerships. Last but not the least, foreign policy making is in many ways an extension of domestic policy making in various arenas and adequate exchange of their respective strengths and expertise of BRICS nations is bound to influence the collective stance of their group in making a case for a fair and just rules of the game when it comes to various regimes governing global governance regimes.

\section{Acknowledgements}

I would like express my thanks to Prof Alka Acharya, Centre for East Asian Studies, School of International Studies, Jawaharlal Nehru University, Delhi, my colleagues Dr Ajay Sharma and Dr Sneha Thapliyal in IIM Indore for giving me valuable feedback of my paper in the first two drafts. I would like to acknowledge the support I got from the BRICS centre, Fudan University, Shanghai. The idea of this paper came during my short stint 
in my capacity as a visiting fellow of the BRICS centre during the period February-April 2014. The fellowship by the BRICS centre helped me collect research material and interact with China based scholars.

\section{References}

[1] Limos, M.C. and Agawam, A. (2006) Environmental Governance. Annual Review Environment Resources, 31, $297-$ 325.

[2] Limos, M.C. and Agawam, A. (2006) Environmental Governance. Annual Review Environment Resources, 31, 298.

[3] Schwartz, J. (2003) The Impact of State Capacity on Enforcement of Environmental Policies: The Case of China. Journal of Environment and Development, 12, 50-81.

[4] State Council (2005) Decision on Embarking on Scientific Approach to Development and Enhancing Environmental Protection. The Third Wave Was Followed by the Earlier Two Waves, the First Wave Being the "Command and Control" System and the Second Wave Being Keeping in Place Certain Policy Instruments to Pursue Environmental Governance.

[5] Teri, O., Bah, H. and Falkner, G. (2007) Modes of Governance: Towards Conceptual Clarification. Journal of European Public Policy, 14., 1-20.

[6] Tung, C.-Y. (2003) China's Fiscal Predicament. American Asian Review, 21, 25-53.

[7] Skocpol, T. and Finegold, K. (1982) State Capacity and Economic Intervention. New Deal, Political Science Quarterly, 97, 255-278.

[8] (2016) Grossly Deceptive Plans, Growth Targets-China's Obsession with GDP Threatens its Economy. The Economist, January 30th.

[9] Zheng, Y.N. and Chen, M.J. (2006) China Promotes Green GDP for Green Economic Development, China Policy Institute, Briefing Series-Issue 16, 2006. The Environment Ministry Is Trying to Create a Measure of "Green GDP" That Could Be Used to Assess the Performance of Local Officials.

[10] Frickel, S. and Davidson, D.J. (2004) Building Environmental States: Legitimacy and Rationalization in Sustainable Governance. International Sociology, 1 March 2004, Sage Publications, 89-110.

[11] Coennan, F., Huitema, D., Toole Jr., O.and Laurence, J. (1998) Participation and Quality of Environmental Decision Making, Springer.

[12] Shie, Y.-J. (2012) The Emergence of Collaborative Environmental Governance in Taiwan: A Changing Landscape of Environmental Politics. Doctoral Thesis, Department of Geography, University College, London.

[13] Popescu, L.-G. (2013) From a Holistic Approach of Public Policy to Co-Governance. Theoretical and Applied Economics, 20, 104.

[14] Taylor, C., Pollard, S., Rocks, S. and Angus, A. (2012) Selecting Policy Instruments for Better Environmental Regulation. Environmental Policy and Governance, 22, 268-292.

[15] Taylor, C., Pollard, S., Rocks, S. and Angus, A. (2012) Selecting Policy Instruments for Better Environmental Regulation. Environmental Policy and Governance, 22, 268-269.

[16] Davidson, D.J. and Frickel, S. (2004) Understanding Environmental Governance: A Critical Review. Organization and Environment, 17, 471-492.

[17] Global Legal Monitor, China: New Implementing Regulations of Law on State Secrets, 31 March 2014.

[18] China's Environment: A Small Breath of Fresh Air. The Economist, 8 February 2014.

[19] Counsellor General of Switzerland, Shanghai. Shanghai Flash. Issue No. 3, August 2009

[20] Wang, Y.L. (2004) Focus on Environmental Protection. Shanghai Daily, 20 January 2014.

[21] China Council for International Cooperation and Development (CCICED) (2013) Media and Public Participation Policies on Promoting China's Green Development. CCICED Special Policy Study Summary Report.

[22] Zhou, X.G., Lian, H., Ortolano, L. and Ye, Y.Y. (2013) A Behavioural Model of "Muddling Through" in the Chinese Bureaucracy: The Case of Environmental Protection. The China Journal, No. 70, 120-147.

[23] Lee, S. (2007) Environmental Movements and Social Organizations in China. China Information, 21, 269-297.

[24] Liu, S. (2012) Environmental NGOs Grow across China but Still Struggle for Support. Global Times, 12 June 2012.

[25] Grunow, D. and Heberer, T. (2011) Environmental Governance in China: New Developments and Perspectives. Journal of Current Chinese Affairs, 40, 3-12.

[26] Thornton, P.M. (2013) The Advance of the Party: Transformation or Takeover of Urban Grassroots Society? The China Quarterly, 213, 1-18. http://dx.doi.org/10.1017/S0305741013000039 
[27] Fulda, A., Li, Y.Y. and Song, Q.H. (2012) New Strategies of Civil Society in China: A Case Study of Networks Approach. Journal of Contemporary China, 21, 675-693. http://dx.doi.org/10.1080/10670564.2012.666837

[28] Jackman, R. (1993) Power without Force: The Political Capacity of Nation States. University of Michigan Press, Ann Arbor.

[29] Kim, H.K. (2003) The Political Capacity of Beijing Still Matters: Political Leadership and Institutionalization of Fiscal Systems during the Period of Economic Decentralization in China, 1979-1997. Doctoral Thesis, University of Michigan, Ann Arbor.

[30] Kyu, K.H. (2002) The Political Capacity of Beijing Still Matters: Political Leadership and Institutionalization of Fiscal Systems during the Period of Economic Decentralization in China: 1979-1997. University of Michigan, Ann Arbor, 33-35. 